Two Found Poems

\title{
Two found poems
}

\section{After you have had your baby}

signals

In the well-established tradition of found poetry, I did not compose the words of these poems. Rather, I have edited and arranged fragments of original texts in order to create new texts in new forms. The words of these poems were found in an information package entitled Caring for yourself and your new baby: Information you need for baby's first days, which was distributed to mothers who had given birth in British Columbia Women's Hospital. I received one of these packages after giving birth to my son in August 2005.

In contemporary North American society most women have little experience of labour, birth, and the care of newborns until they actually become mothers. For several generations, birthing has mostly taken place outside of the home in hospital settings.

Girls and women are no longer required to attend or assist with the births of women in their families and local communities. So unlike their foremothers, most first time mothers gain practical knowledge of caring for tiny babies "on the job". In order to facilitate this process, hospitals have taken on a pedagogical as well as medical role.

Mothers who give birth in hospital are provided with a great deal of written material containing information on every aspect of a mother's duties: caring for a new baby, breastfeeding, adjustment to the demands of motherhood, as well as instruction on how to maintain her own physical and emotional health. Some of the information covers rare life-threatening childhood diseases and illnesses, child safety, postnatal depression 
and psychosis, and so forth. This bombardment of instruction comes at a time of significant physical, emotional, and social change for the new mother. Many women will find the required standards of mothering beyond the scope of the material and economic conditions in which they live and must mother. Indeed, many women will not even have the literacy skills required to wade their way through the material.

Although these hospital information packages can be invaluable resources for new mothers, they also have a darker ideological subtext. In crafting these two found poems I seek to bring to the fore this narrative subtext, highlighting the ways that language is used - whether consciously or not - to create, shape and even “disappear" women's diverse realities and experiences of mothering.

Of interest to me are the infantilizing and controlling discourses of domestication and medicalization, and the insidious ways in which they render women's bodies powerless and inadequate to the complex tasks of mothering. The language and structure of the poems reveal the excessive, contradictory, and at times somewhat threatening and overly demanding narratives of such discourses. In particular, I explore how the "shadow side" of mothering - often experienced as social isolation, fear, anger, despair and depression - is pathologized by the prevailing mythologies of motherhood. 


\section{After you have had your baby}

Make time for exercise daily.

Join a Postpartum Exercise Class:

Kegel's, Super Kegel's, The Pelvic Tilt,

Abdominal Exercises.

Spend time with your baby.

How do I hold my baby?

How do I breastfeed my baby?

How do I latch my baby?

Modified Cradle, Cradle, Football, Lying down.

Relax.

Talk about medication:

Tylenol Plain; Tylenol \#3, Advil, Motrin, Laxatives (Colace, Glycerin Rectal Suppositories, Magnolax), Iron, Anusol HC Ointment.

Stand tall.

Massage your breasts.

Express milk every 3 hours

if your baby is unable to nurse.

(8 times in 24 hours.)

Sleep.

Very tired. Sore nipples. Engorgement. Leaking. Lumps. Mastitis. Jaundice. Projectile vomiting.

Too much milk. Too little milk.

Feeds constantly.

Avoid jumping.

Contact your library, your hospital nurse, community health nurse, doctor, midwife, La Leche League. Explore the internet. Make sure the information is up-to-date.

Rest.

Resting does not help. 
You pass clots, bleed heavier, have fever, chills, pain, hemorrhoids, problems passing urine, stitches open up.

Congratulations! 


\title{
signals
}

having a baby

is a normal natural event

being a new mother

is exciting

\author{
having a baby \\ is a lonely frightening experience \\ it is difficult to know \\ what to do
}

take frequent breaks

for a cup of tea

or a bath

have lunch with a friend

take a walk

explore a bookstore

get a babysitter

you deserve one

$$
\begin{aligned}
& \text { grieve } \\
& \text { feel sad } \\
& \text { feel angry } \\
& \text { irritation } \\
& \text { resentment } \\
& \text { frustration } \\
& \text { rage } \\
& \text { toward your baby }
\end{aligned}
$$

do good things

for yourself

make a point of it

spend time thinking

about what's for you

explore good feelings

cultivate joy

love and happiness

$$
\begin{aligned}
& \text { crying for no reason } \\
& \text { depression } \\
& \text { feelings of guilt } \\
& \text { overconcern for your baby } \\
& \text { inability to cope } \\
& \text { helplessness }
\end{aligned}
$$


anxiety

feelings of inadequacy

signals

\section{no feelings}

reach out

help 